Удк 342.59

DOI https://doi.org/10.32837/apdp.v0i89.3188

H. I. Mamam

\title{
ПРОГАЛИНИ У ПРАВОВОМУ РЕГУЛЮВАННІ ЯК КОРУПЦІОГЕННИЙ ФАКТОР У ДІЯЛЬНОСТІ ОРГАНІВ ПУБЛІЧНОЇ ВЛАДИ
}

Постановка проблеми. Загальновідомим є той факт, що проблеми, які породжуються корупцією, створюють серйозну загрозу для стабільності й безпеки суспільства, підривають демократичні інститути та завдають шкоди стійкому розвитку правопорядку. Саме тому важливого значення набуває дослідження правових причин корупції, через існування яких нормативна основа правового регулювання виявляється неспроможною ефективно протидіяти корупційним ризикам, що притаманні насамперед сфері діяльності органів публічної влади.

Стан наукових досліджень. Проблематика корупціогенних факторів у сфері державної служби, а також окремі ї̈ аспекти досліджувалася такими вченими, як Ю.Г. Арзамасов, О. Р. Дашковська, М. О. Лисенко, М. І. Мельник, М. В. Романов, М. В. Романюк, М. І. Хавронюк, С.В. Якимова та ін. Разом із цим окремі питання наведеної проблематики, зокрема щодо визначення правових (юридичних) причин наявності корупціогенних факторів у діяльності органів публічної влади, зумовлених в першу чергу недоліками правового регулювання, а також аналізу шляхів їх усунення залишаються недостатньо розробленими, що з огляду на важливе практичне значення указаних питань зумовлює актуальність їх дослідження.

Метою статті є з'ясування впливу прогалин у правовому регулюванні як корупціогенного фактора на функціонування органів публічної влади, а також дослідження шляхів усунення зазначених недоліків права, що має на меті запобігати вчиненню корупційних правопорушень та правопорушень, пов'язаних із корупцією, в публічній сфері.

Виклад основного матеріалу. Під прогалиною у правовому регулюванні в теорії права розуміють повну або часткову відсутність нормативної регламентації певних суспільних відносин, що знаходяться у сфері правового регулювання. Юридична наука традиційно розглядає прогалини в правовому регулюванні як дефект права. Разом із цим негативний вплив прогалин полягає не лише в їх здатності розмикати систему права, нівелюючи його внутрішню узгодженість, а й у можливості виступати самостійним корупціогенним фактором у діяльності органів публічної влади.

Так, корупціогенність прогалин виявляється у їх здатності сприяти особі, яка уповноважена застосовувати норми певного організаційно-розпорядчого чи іншого документа, тлумачити його на власний розсуд, обирати із кількох можливих той варіант поведінки, який є найбільш вигідним для неї. Класифікуючи прогалини у правовому регулюванні як корупціогенний фактор, можна виділити такі їх види: а) прогалини в нормах матеріального права; б) відсутність або недостатність контролю і прозорості; в) відсутність або недостатність адміністративних і судових процедур; г) відсутність або недостатність конкурсних (аукціонних) процедур [1]. 
При цьому під корупціогенним фактором, згідно із затвердженою Міністерством юстиції України Методологією проведення антикорупційної експертизи (далі Методології), слід розуміти здатність нормативно-правової конструкції (окремого нормативного припису чи їх сукупності) самостійно чи у взаємодії з іншими нормами сприяти вчиненню чи збільшенню корупційних правопорушень або правопорушень, пов'язаних із корупцією [2]. У контексті досліджуваної проблематики відзначимо, що зазначені корупціогенні фактори правового регулювання можуть полягати як у неврегульованості, так і в недостатній урегульованості суспільних відносин в окремих сферах [3, с. 140].

Прогалини в нормах матеріального права стають фактором корупціогенності у випадку повної або часткової відсутності конкретного нормативно-правового припису, який би визначав функції, права, обов'язки і відповідальність органів державної влади та місцевого самоврядування, осіб, уповноважених на виконання функцій держави або місцевого самоврядування.

Яскравим прикладом ситуації, до якої призводять прогалини в нормах матеріального права, що регламентують діяльність органів публічної влади, може бути наступний випадок. Так, у 2005 р. однією з районних державних адміністрацій в Харківській області в особі її голови було укладено договір оренди землі з підприємцем. За вказаним договором районна державна адміністрація надала в оренду суб'єкту господарювання земельну ділянку площею 34,78 га водного фонду строком на 49 років з орендною платою у розмірі 100 грн. за 1 га на рік. У подальшому за результатами аудиту було встановлено, що орендна плата, встановлена цим договором, є заниженою та не відповідає ринковій вартості оренди указаної категорії земель. Зазначена ситуація стала можливою внаслідок відсутності на час укладення згаданого договору відповідних нормативно-правових приписів, які б затверджували методику визначення розміру плати за надання в оренду земель водного фонду. Відтак у розглядуваному випадку відсутність у законодавстві порядку визначення розміру плати за надання в оренду земель зазначеної категорії виступає корупціогенним фактором, адже законодавством головам районних державних адміністрацій було надано надмірно широкі повноваження щодо визначення на власний розсуд розміру плати за надання в оренду згаданої категорії земель із одночасною відсутністю юридичних засобів, що могли б забезпечити застосування цих дискреційних повноважень у чітко визначеному обсязі, необхідному для належного виконання особою, уповноваженою на виконання функцій держави, своїх прав і обов'язків із метою, задля досягнення якої їх було надано.

3 огляду на те, що неналежне визначення в нормативно-правовому акті (чи його проекті) функцій, прав, обов'язків і відповідальності органів державної влади та місцевого самоврядування, осіб, уповноважених на виконання функцій держави або місцевого самоврядування, є найпоширенішим корупціогенним фактором у діяльності органів публічної влади, проаналізуємо його більш детально. Так, згідно з п. 2.2. Методології неналежним визначенням функцій, прав, обов'язків і відповідальності органів державної влади та місцевого самоврядування, осіб, уповноважених на виконання функцій держави або місцевого самоврядування, в нормативно-правовому акті, проекті нормативно-правового акта можуть бути: 
1) наявність дискреційних повноважень, не зумовлених специфікою суспільних відносин, що регулюються нормативно-правовим актом, або які передбачається врегулювати проектом нормативно-правового акту, а також відсутність юридичних засобів, що можуть забезпечити застосування дискреційних повноважень в обсязі і з метою, для якої ці повноваження надані особі, уповноваженій на виконання функцій держави або місцевого самоврядування; 2) неврегульованість процедури вирішення потенційного чи реального конфлікту інтересів у разі можливості його виникнення; 3) відсутність чітких критеріїв оцінки діяльності особи, уповноваженої на виконання функцій держави або місцевого самоврядування, та механізмів контролю за її діяльністю; 4) невизначеність меж персональної відповідальності особи, уповноваженої на виконання функцій держави або місцевого самоврядування, за свої рішення, дії чи бездіяльність [2].

При цьому способами усунення зазначеного корупціогенного фактора, згідно з Методологією [2], є включення до нормативно-правового акта чи проекта такого акта норм, які: а) дозволяють визначити осіб, відповідальних за виконання тієї чи іншої державної функції або надання адміністративної послуги; б) встановлюють для осіб, уповноважених на виконання функцій держави або місцевого самоврядування, додаткові заборони, обмеження чи покладають додаткові обов'язки; в) передбачають запровадження додаткових критеріїв оцінки якості ефективності і результативності службової діяльності; г) уточнюють обсяг службової діяльності конкретних осіб, уповноважених на виконання функцій держави або місцевого самоврядування; д) встановлюють додаткові механізми взаємодії осіб, уповноважених на виконання функцій держави або місцевого самоврядування, як всередині органу публічної влади, так і з такими особами інших органів публічної влади.

Серед інших видів прогалин у правовому регулюванні, які є корупціогенними факторами в діяльності органів публічної влади, можна указати на такі, як:

1) відсутність або недостатність контролю і прозорості. Так, окремим корупціогенним фактором є відсутність у законодавстві приписів, що встановлювали б належний контроль за виконанням повноважень осіб, уповноважених на виконання функцій держави, та обгрунтованістю прийнятих ними рішень, а також забезпечували б необхідний рівень прозорості діяльності органів публічної влади (що, зокрема, включає вимогу до таких органів оприлюднювати важливу та актуальну інформацію про свій персонал та структуру, повноваження і функції, фінанси, поточні заходи та плани, проголошені політичні ініціативи та ухвалені рішення, послуги, які надаються мешканцям, а також інформацію, що становить суспільний інтерес [4, с. 40]);

2) відсутність або недостатність адміністративних і судових процедур. Цей корупціогенний фактор характеризується відсутністю в нормативно-правовому акті чи проекті такого акта, яким регламентується реалізація суб'єктивних прав та виконання юридичних обов'язків фізичними та юридичними особами, адміністративних або судових процедур або наявністю у нормативно-правовому акті (чи його проекті) нечіткостей встановленої адміністративної чи судової процедури, що здатні створити умови для вчинення корупційних правопорушень або правопорушень, пов’язаних із корупцією; 
3) відсутність або недостатність конкурсних (аукціонних) процедур. Під цим фактором корупціогенності слід розуміти відсутність у нормативно-правовому акті чи проекті такого акта конкурсних (тендерних) процедур (якщо це безпосередньо передбачено цим нормативно-правовим актом чи проектом такого акта або актом, пов'язаним із ним) або наявність недоліків установленої конкурсної (тендерної) процедури, що здатні створити умови для здійснення корупційних дій або виникнення корупційних відносин.

Усуненню зазначених корупціогенних факторів покликана сприяти антикорупційна експертиза, яка являє собою діяльність із виявлення в нормативно-правових актах, проектах нормативно-правових актів положень, які самостійно чи в поєднанні з іншими нормами можуть сприяти вчиненню корупційних правопорушень або правопорушень, пов'язаних із корупцією. Так, відповідно до Методології проведення антикорупційної експертизи під час проведення експертизи здійснюються виявлення та оцінка таких корупціогенних факторів: 1) нечітке визначення функцій, прав, обов'язків і відповідальності органів державної влади та місцевого самоврядування, осіб, уповноважених на виконання функцій держави або місцевого самоврядування; 2) створення надмірних обтяжень для одержувачів адміністративних послуг; 3) відсутність або нечіткість адміністративних процедур; 4) відсутність чи недоліки конкурсних (тендерних) процедур [2].

Як відзначає професор О.Р. Дашковська, антикорупційна експертиза - це певний етап правового моніторингу, який може здійснюватися, по-перше, безпосередньо розробниками нормативних правових актів, по-друге, співробітниками правових та аналітичних служб, по-третє, це може бути незалежна експертиза інститутів громадянського суспільства (громадських організацій, торгово-промислових палат тощо) i, звичайно, експертиза з метою здійснення правового контролю, виявлення корупціогенних факторів під час здійснення державної реєстрації органами Міністерства юстиції України [5, с. 20]. Правовий моніторинг полягає, зокрема, у виявленні суперечностей, колізій, прогалин у правовому регулюванні, результатом якого є вироблення пропозицій щодо вдосконалення законодавчого акта [6, с. 140]. Зокрема, тільки за результатами моніторингу експерт може отримати відповіді на такі питання експертизи проекта нормативно-правового акта, як: наскільки повно врегульовані в запропонованому нормативно-правовому акті питання, що становлять його предмет; чи не залишаться прогалини в законодавстві після прийняття даного акта; чи немає в нормативно-правовому акті надлишкових норм, тобто норм, без яких цілі нормативно-правового акта все одно будуть досягнуті; чи відповідають очікувані витрати поставленим цілям тощо [5, с. 20].

Аналіз ст. 55 Закону України «Про запобігання корупції» від 14.10.2014 № 1700-VII [7] (далі - Закону № 1700-VII) дозволяє здійснити класифікацію антикорупційної експертизи на державну та незалежну, а також обов'язкову та ініціативну. Слід відзначити, що законодавцем досить вичерпно врегульовано порядок проведення державної антикорупційної експертизи, натомість питання проведення незалежної експертизи на сьогодні не дістали докладної нормативної регла- 
ментації. Так, відповідно до ч. 7, 8 ст. 55 Закону № 1700-VII за ініціативою фізичних осіб, громадських об'єднань, юридичних осіб може проводитися громадська антикорупційна експертиза чинних нормативно-правових актів та проектів нормативно-правових актів. Результати такої експертизи підлягають обов'язковому розгляду суб’єктом видання (прийняття) відповідного акта, його правонаступником або суб'єктом, до якого перейшли відповідні нормотворчі повноваження в даній сфері. Разом із цим вважаємо, що з метою забезпечення можливості проведення незалежної антикорупційної експертизи проектів нормативно-правових актів, що зачіпають права, свободи й обов'язки людини і громадянина, або тих, що мають міжвідомчий характер, слід на законодавчому рівні встановити обов'язок для органів державної виконавчої влади та органів місцевого самоврядування перед ухваленням нормативно-правового акта розміщувати проекти цих актів (за винятком проектів нормативно-правових актів, що містять відомості, які становлять державну таємницю або ухвалюються у зв'язку з введенням воєнного або надзвичайного стану) на офіційному сайті органу державної влади чи місцевого самоврядування із зазначенням дати початку та закінчення приймання висновків за результатами незалежної антикорупційної експертизи.

Окрім цього, слушною видається висловлена в науковій літературі пропозиція щодо необхідності законодавчого закріплення статусу експерта, уповноваженого на проведення експертизи чинних нормативно-правових актів, а також проектів нормативно-правових актів на предмет наявності факторів корупціогенності, та доцільності розроблення механізму акредитації вищезазначених незалежних експертів [8, с. 102], що також значно сприяло б підвищенню якості та забезпеченню неупередженості результатів такої експертизи.

Висновки. Будучи одним із дефектів права, прогалини позбавляють право необхідної визначеності, нерідко стаючи при цьому одним із факторів корупціогенності в публічно-правових відносинах. Усунення цього корупціогенного фактора в діяльності органів публічної влади має відбуватися насамперед шляхом моніторингу проектів нормативно-правових актів, невід'ємною складовою частиною якого $€$ антикорупційна експертиза. Водночас аналіз вітчизняного досвіду проведення цього виду правової експертизи дає підстави стверджувати, що подальше реформування сфери нормотворчої діяльності має здійснюватися в напрямку широкого залучення громадських об'єднань та окремих незалежних експертів до проведення антикорупційної експертизи нормативно-правових актів та їх проектів, що дозволить значно підвищити ефективність цього інструменту і сприятиме забезпеченню розумного балансу між приватними і загальносоціальними інтересами. 


\section{Jimepamypa}

1. Методика і практика проведення громадської антикорупційної експертизи регуляторних актів місцевого рівня : проект USAID «Впевнений бізнес - заможна громада» URL : https://platforma-msb.org/ wp-content/uploads/2016/01/Anticorruption-workshop.pptx (дата звернення: 24.02.2021).

2. Методологія проведення антикорупційної експертизи : затверджена наказом Міністерства юстиції України від 24.04.2017 № 1395/5. URL : https://zakon.rada.gov.ua/laws/show/ v1395323-17\#n8 (дата звернення: 24.02.2021).

3. Запобігання корупції : підручник / Б.М. Головкін, О.Ю. Шостко, О.В. Новіков та ін. ; за заг. ред. Б.М. Головкіна. Харків : Право, 2019. 296 с.

4. Яцко Т., Вакуленко В. Прозорість, відкритість, зрозумілість : навч. модуль / ред. Т. Яцко. URL : https://www.nispa.org/files/publications/training/Transparency_openness_intelligibilityUA.pdf (дата звернення: 24.02.2021).

5. Дашковська O.Р. Антикорупційна експертиза як складова єдиного правового моніторингу нормативних правових актів. Порівняльно-аналітичне право. 2015. № 5. С. 18-21.

6. Онищук I.I. Правовий моніторинг із залученням громадських об'єднань та наукових інституцій. Вісник Національного університету «Львівська політехніка». Юридичні науки. 2014. № 801. C. 139-146.

7. Про запобігання корупції : Закон України від 14.10.2014 № 1700-VII. Голос України. 2014. 25 жовтня (№ 206).

8. Романюк М.В. Деякі питання антикорупційної експертизи в адміністративному судочинстві. Наук. вісн. публіч. та приват. права : зб. наук. пр. 2018. Вип. 6. Т. 2. С. 98-103.

\section{Анотація}

Матат Ю. І. Прогалини в правовому регулюванні як корупціогенний фактор у діяльності органів публічної влади. - Стаття.

Стаття присвячена з'ясуванню впливу прогалин у правовому регулюванні як корупціогенного фактора на функціонування органів публічної влади, а також дослідженню шляхів усунення зазначених дефектів права, що має на меті запобігати вчиненню корупційних правопорушень та правопорушень, пов'язаних із корупцією, у публічній сфері.

Визначено, що прогалину у правовому регулюванні слід розглядати як корупціогенний фактор, який сприяє особі, що уповноважена застосовувати норми певного організаційно-розпорядчого чи іншого документа, тлумачити його на власний розсуд, обирати із кількох можливих той варіант поведінки, який є найбільш вигідним для неї. Здійснено класифікацію прогалин, які є корупціогенним фактором, на такі види: а) прогалини в нормах матеріального права; б) відсутність або недостатність контролю і прозорості; в) відсутність або недостатність адміністративних і судових процедур; г) відсутність або недостатність конкурсних (аукціонних) процедур.

Обгрунтовано, що найпоширенішим корупціогенним фактором у діяльності органів публічної влади є неналежне визначення в нормативно-правовому акті (його проекті) функцій, прав, обов’язків і відповідальності органів державної влади та місцевого самоврядування, осіб, уповноважених на виконання функцій держави або місцевого самоврядування, наслідком чого може бути невиправдане встановлення чи надмірне розширення дискреційних повноважень, створення умов для виникнення конфлікту інтересів та можливостей для зловживання наданими їм повноваженнями.

Зроблено висновок, згідно з яким усунення прогалин у правовому регулюванні, що стають фактором корупціогенності у публічно-правових відносинах, має відбуватися насамперед шляхом моніторингу нормативно-правових актів, невід'ємною складовою частиною якого є антикорупційна експертиза. Водночас подальше реформування сфери нормотворчої діяльності має відбуватися у напрямку широкого залучення громадських об’єднань та окремих незалежних експертів до проведення антикорупційної експертизи нормативно-правових актів та їх проектів, що дозволить підвищити ефективність цього інструменту й сприятиме забезпеченню розумного балансу між приватними і загальносоціальними інтересами.

Ключові слова: корупціогенний фактор, прогалини у правовому регулюванні, антикорупційна експертиза, моніторинг нормативно-правових актів, методологія антикорупційної експертизи. 


\section{Summary}

Matat Yu. I. Gaps in legal regulation as a corruption-causing factor in the activities of public authorities. - Article.

The article is devoted to clarification of the impact of gaps in legal regulation as a corruption-causing factor on functioning of public authorities, as well as the study of ways to eliminate these defects of law, aimed at preventing corruption and corruption-related offenses in the public sphere.

It is determined that the gap in the legal regulation shall be considered as a corruption-causing factor that contributes to the person authorized to apply the rules of a certain organizational or administrative document, interpret it at its discretion, choose the most beneficial to her/him from several possible behaviours. The classification of gaps, which are a corruption-causing factor, into the following types: a) gaps in substantive law; b) lack or lack of control and transparency; c) absence or insufficiency of administrative and judicial procedures; d) absence or insufficiency of competitive (auction) procedures.

It is substantiated that the most common corruption-causing factor in the activities of public authorities is the improper definition in the normative legal act (its draft) of functions, rights, duties and responsibilities of public authorities and local governments, persons authorized to perform state or local government functions, which may result in unjustified establishment or excessive expansion of discretionary powers, creating conditions for conflicts of interest and opportunities for abuse of their powers.

It is concluded that the elimination of gaps in legal regulation, which become a factor of corruption in public relations, should be done primarily through monitoring of regulations, an integral part of which is anti-corruption expertise. At the same time, further reform of the sphere of rule-making activity should take place in the direction of broad involvement of public associations and individual independent experts in conducting anti-corruption examination of normative legal acts and their drafts, which will increase the effectiveness of this tool and ensure a reasonable balance between private and public interests.

Key words: corruption factor, gaps in legal regulation, anti-corruption expertise, monitoring of normative legal acts, methodology of anti-corruption expertise. 